\title{
Basic Psychological Needs and Their Association with Academic Factors in the Spanish University Context
}

\author{
Ramón Chacón-Cuberos ${ }^{1}$ D , Amador Jesús Lara-Sánchez ${ }^{2}$ iD and Manuel Castro-Sánchez $^{3, *(D)}$ \\ 1 Department of Research Methods and Diagnosis in Education, University of Granada, 18071 Granada, Spain; \\ rchacon@ugr.es \\ 2 Department of Didactics of Musical, Plastic and Corporal Expression, University of Jaén, 23071 Jaén, Spain; \\ alara@ujaen.es \\ 3 Department of Didactics of Musical, Plastic and Corporal Expression, University of Granada, \\ 52071 Melilla, Spain \\ * Correspondence: manuelcs@ugr.es; Tel.: +34-958-248-949
}

Citation: Chacón-Cuberos, R.;

Lara-Sánchez, A.J.; Castro-Sánchez,

M. Basic Psychological Needs and

Their Association with Academic

Factors in the Spanish University

Context. Sustainability 2021, 13, 2449.

https://doi.org/10.3390/su13052449

Academic Editor: Carlos Salavera

Received: 31 January 2021

Accepted: 18 February 2021

Published: 24 February 2021

Publisher's Note: MDPI stays neutral with regard to jurisdictional claims in published maps and institutional affiliations.

Copyright: (c) 2021 by the authors. Licensee MDPI, Basel, Switzerland. This article is an open access article distributed under the terms and conditions of the Creative Commons Attribution (CC BY) license (https:/ / creativecommons.org/licenses/by/ $4.0 /)$.

\begin{abstract}
Motivational development represents a key element for academic performance in the university context. A non-experimental study with a cross-sectional and ex post facto design through a single measurement in a single group was conducted. The sample was made up of a total of 2736 university students $\left(\sigma^{n}=33.8 \%(n=924) ; \uparrow=66.2 \%(n=1812)\right)$ belonging to a total of 19 Spanish universities. The main instrument used was the Basic Psychological Needs scale, using the IBM SPSS 22.0 (IBM Corp., Armonk, NY, USA) software for data analysis. The results showed that the need for autonomy was higher in social sciences students, those who accessed their studies through vocational training and those who attended their degree in person. In addition, this need was positively related to score, but inversely related to age and grade. The need for competence was higher in students who studied in private centers, those who accessed their university studies through other ways and those students who studied online. Likewise, this need was directly related to the score. Finally, it should be noted that the need for relationships was higher in university students from public institutions, students who accessed their studies through vocational training and those who studied in face-to-face universities. The need for a relationship correlated positively with the score, although with less strength than other needs. In this way, the relevance of various academic factors in the motivational development of students can be established, from which various educational implications are derived in order to favor academic performance.
\end{abstract}

Keywords: higher education; motivation; academic performance; grant; teaching

\section{Introduction \\ 1.1. Emerging Adulthood and University}

Emerging adulthood is defined as the stage of transition between adolescence and adulthood, characterized mainly by the young adult's beginning in the world of work, the completion of higher education or the development of personal identity [1]. Among its characteristics, this period stands out for the youth's search for autonomy, having just left adolescence. In this sense, there is an emancipation of the family home, new social relationships are built and an exploration of social identity occurs that culminates in its consolidation [2,3]. All these elements, together with the socio-labor possibilities and the optimism that characterize the stage, make emerging adulthood become a period of certain complexity. This is because certain goals and obligations are combined (academic success, job search, reconciling personal and social life) with the development of several habits and behaviors that can be harmful (substance use, digital leisure habits or inappropriate eating behavior) $[4,5]$.

Some researchers have shown interest in the study of academic performance within the university context, showing a certain complexity due to the characteristics of the 
evolutionary period [5-7]. Higher education represents the educational stage in which young university students acquire knowledge and skills that allow them to enter the world of work. This is done through university degrees (professionalizing degrees) that bring together relevant theoretical and practical training in order to achieve a learning that provides the student with competence to develop a professional activity $[8,9]$. Therefore, the characteristics of the training to be developed, together with those of the young university student, make this period difficult. In fact, university dropout rates are close to $25 \%$ in many European countries [10].

Respondek et al. [11] highlight the interest in analyzing which are the determining factors for the achievement of a good academic performance, as defined mainly by the number of credits passed and the grades obtained. Variables associated with the teaching process, such as the content to be worked on, the methodology used, the teaching leadership or the resources used will be decisive in achieving a high success rate [1,12]. In addition, contextual elements such as family situation, economic status or socio-demographic factors must also be considered [1,5]. Nevertheless, it is necessary to pay attention to cognitive and psychological factors in order to achieve optimal performance. These factors are the student's capacity for emotional regulation, self-efficacy, perceived well-being or motivational development [12,13]. In fact, Ketonen [14] and Chacón-Cuberos et al. [15] point out the relevance of this last factor when it comes to achieving a goal or objective.

\subsection{Motivation and Academic Achievement}

Motivation can be understood as the energy that a person mobilizes when carrying out an action or setting a goal. Several authors have shown that students who have more emotional resources and who set achievable goals maintain levels of motivation over time to achieve success $[14,16]$. In this sense, the development of intrinsic motivations is relevant as they are linked to higher levels of satisfaction, prolongation of the behavior over time and success in achieving goals [17]. Extrinsic motivations have also been shown to be decisive, but these are associated with lower success rates and higher dropouts when external regulation ceases [18].

This research focuses on the theory of self-determination [19] to explain motivational processes in the academic context. This theory establishes that the motivation to carry out a task varies in a "continuum" of self-determination. Thus, intrinsic motivation is found in the most self-determined zone, extrinsic motivation in the intermediate zones, and demotivation in the least self-determined zone [20]. From this theory emanated the "Six Micro-Theories", within which is highlighted the theory of basic psychological needs (BPN): autonomy, competence and relationship with others. This theory establishes that when a person is able to satisfy these three needs, they will develop self-determined motivations, which will favor achievement and success $[19,21]$. Specifically, it has been shown how the development of BPN is positively associated with academic performance [22].

The role of BPN has been widely studied, including in relation to other factors of relevance to academic performance. For example, Campbell et al. [23] demonstrated the association of these needs with stress and sleep time during exams, as well as how the satisfaction of BPN decreased levels of stress and anxiety and generated a change in the quality of sleep and academic performance. Other research, such as that of Van Roy et al. [24], demonstrated how an educational program based on gamification favored the development of BPN in Master's students, achieving higher levels of interest and participation. Moreover, Schenkenfelder et al. [25] revealed how professional and peer support favor these needs in the university context, achieving greater motivational development and academic satisfaction. Therefore, this study examines the following research question: Do basic psychological needs depend on academic factors such as the area of knowledge or the teaching modality?

Finally, the aim of this study is to determine the differences in the development of the three BPN according to academic factors such as the area of knowledge, the typology of 
the university institution, the teaching modality or training prior to university. In this way, two hypotheses are specified:

- (H1) The teaching modality and the access route to the university are determining factors in the development of BPN.

- $\quad(\mathrm{H} 2)$ The area of knowledge and the typology of the university institution are not influential for BPN.

\section{Materials and Methods}

\subsection{Design and Participants}

A quantitative and non-experimental study was carried out, with a cross-sectional and ex post facto design through a single measurement in a single group. The sample was made up of a total of 2736 university students $\left(\sigma^{n}=33.8 \%(n=924) ;\right.$ i $\left.=66.2 \%(n=1812)\right)$ belonging to a total of 19 Spanish universities. The population universe was represented by a total of 1,289,233 university students enrolled in undergraduate degrees in the $2017 / 2018$ academic year, according to the Ministry of Education (Spain). The inclusion criterion used required them to be enrolled in at least $60 \%$ of the credits for an academic year. The exclusion criterion used was failing to pass at least $50 \%$ of the enrolled credits. Sampling was based on convenience following the criteria set by Bartlett et al. [26]. Likewise, an error of $1.7 \%$ was presented ( $95 \%$ confidence interval and sampling error of 0.017 ).

\subsection{Instruments}

- The basic psychological needs scale was initially validated by Sheldon et al. [27] and adapted into Spanish by Reggiani [28]. Our questionnaire is made up of 12 items (e.g., "1. The tasks that I carry out are adjusted to my interests") that are scored using a Likert-type scale with five response options ( $1=$ Totally disagree; $5=$ Totally agree). The items in this questionnaire are grouped into three basic dimensions: need for autonomy (Items 1, 4, 7 and 10), need for competence (Items 2, 5, 8 and 11) and need for relationship (Items 3, 6, 9 and 12). For this scale, an internal consistency of $\alpha=0.858$ was obtained, which is considered acceptable.

- A self-prepared questionnaire (ad hoc) in which all sociodemographic variables are included. Variables related to academic aspects are also considered, such as: area of knowledge, type of university, access to university and type of teaching.

\subsection{Procedure}

This study was carried out in March 2019. First, we proceeded to request the informed consent of the participants. All respondents were over 18 years of age. This process was carried out through an informative document, sent online, in which the objective of the study, the instruments to be used, the data analysis and the participants' right to confidentiality were detailed.

Subsequently, the validated scales were applied to all subjects who agreed to participate in the research and who had given their informed consent. The time spent in completing the questionnaire was about $15 \mathrm{~min}$. After finishing, we thanked the subjects for their participation and the scores obtained on the scales were sent. This research process observed the ethical standards for research with humans established in the Declaration of Helsinki.

Data treatment and purification were carried out using the IBM SPSS 22.0 software (IBM Corp., Armonk, NY, USA). During this process, all the questionnaires that presented an error were deleted. The respondents were also filtered based on the inclusion and exclusion criteria that were previously set. This transcription process was carried out by the main research investigator in order to ensure correct statistical treatment and avoid errors in the development of the data matrix. 


\subsection{Data Analysis}

The statistical package IBM SPSS 22.0 (IBM Corp, Armonk, NY, USA) was used to analyze the data. For the analysis of the basic descriptive statistics, frequencies and means were used. In order to determine the existence of statistically significant differences between variables, a comparison of the means of independent samples was performed using the Student's T-test and one-way ANOVA. The normality of the data was verified through the Kolmogorov-Smirnov test. Likewise, the homogeneity of variances was contrasted through the Levene test. The inter-group comparison was carried out using Duncan's test as a post hoc test. It should be noted that the internal reliability of the instruments used was assessed using Cronbach's alpha, setting the reliability index at $95.5 \%$.

\section{Results}

Table 1 shows the BPN according to the academic factors analyzed. The T-test carried out for the area of knowledge revealed statistically significant differences in the need for autonomy $(\mathrm{T}=2.335 ; p=0.020)$ reflecting a higher mean score in social sciences ( $3.57 \pm 0.69$ vs. $3.50 \pm 0.67$ ). Following this line, the comparison of means according to the type of university showed statistically significant differences in the need for competence $(\mathrm{T}=-3.004 ; p=0.003)$, showing higher values for private institutions $(3.98 \pm 0.58 \mathrm{vs}$. $4.16 \pm 0.64)$. On the other hand, statistically significant differences were also obtained for the need for relationship $(T=3.165 ; p=0.002)$, which was higher in public institutions $(4.08 \pm 0.75$ vs. $3.83 \pm 0.86)$.

Table 1. Basic psychological needs (BPN) according to academic factors.

\begin{tabular}{|c|c|c|c|c|}
\hline \multirow{2}{*}{ Variables } & \multirow{2}{*}{ Categories } & \multicolumn{3}{|c|}{$\mathbf{M} \pm \mathbf{S D}$} \\
\hline & & N-A & $\mathrm{N}-\mathrm{C}$ & N-R \\
\hline \multirow{3}{*}{$\begin{array}{c}\text { Area of } \\
\text { knowledge }\end{array}$} & Social & $3.57 \pm 0.69$ & $4.00 \pm 0.58$ & $4.08 \pm 0.78$ \\
\hline & Health & $3.50 \pm 0.67$ & $3.98 \pm 0.58$ & $4.06 \pm 0.70$ \\
\hline & (Sig.) & * & 0.388 & 0.659 \\
\hline \multirow{3}{*}{ Typology } & Public & $3.55 \pm 0.68$ & $3.98 \pm 0.58$ & $4.08 \pm 0.75$ \\
\hline & Private & $3.43 \pm 0.74$ & $4.16 \pm 0.64$ & $3.83 \pm 0.86$ \\
\hline & (Sig.) & 0.085 & $* *$ & ** \\
\hline \multirow{4}{*}{ Teaching } & Face to face & $3.57 \pm 0.67^{d}$ & $3.99 \pm 0.57$ & $4.09 \pm 0.74^{\mathrm{d}}$ \\
\hline & Mixed & $3.35 \pm 0.69$ & $3.83 \pm 0.58$ & $3.90 \pm 0.82$ \\
\hline & Online & $3.39 \pm 0.74$ & $4.11 \pm 0.71^{\mathrm{d}}$ & $3.99 \pm 0.89$ \\
\hline & (Sig.) & $* * *$ & $* * *$ & $* *$ \\
\hline \multirow{4}{*}{ Access } & Baccalaureate & $3.53 \pm 0.67$ & $3.96 \pm 0.58$ & $4.06 \pm 0.74$ \\
\hline & $\mathrm{VT}$ & $3.62 \pm 0.71$ & $4.02 \pm 0.57$ & $4.14 \pm 0.74$ \\
\hline & Other & $3.50 \pm 0.68$ & $4.10 \pm 0.59$ & $3.98 \pm 0.89$ \\
\hline & (Sig.) & $* *$ & $* * *$ & $* *$ \\
\hline
\end{tabular}

Note 1: N-A: need for autonomy; N-C: need for competence; N-R: need for relationship; VT: vocational training Note 2: $\mathrm{M} \pm$ SD: mean \pm standard deviation; Sig.: significance; ${ }^{\mathrm{d}}$ : Duncan's test (post hoc). Note 3: * Statistically significant differences at the $p<0.05$ level; ${ }^{* *}$ Statistically significant differences at the $p<0.01$ level; *** Statistically significant differences at the $p<0.005$ level.

Subsequently, the BPN are shown according to the type of teaching, and statistically significant differences were found for all the dimensions studied. The need for autonomy showed the highest mean value for face-to-face teaching, followed by online and semi-faceto-face teaching with similar values ( $3.57 \pm 0.67$ vs. $3.35 \pm 0.69$ vs. $3.39 \pm 0.74 ; \mathrm{F}=12.357$; $p<0.001)$. The need for competence reflected an inverse trend, showing the highest score for the online modality, followed by face-to-face and semi-face-to-face (3.99 \pm 0.57 vs. 
$3.83 \pm 0.58$ vs. $4.11 \pm 0.71 ; \mathrm{F}=9.298 ; p<0.001)$. Finally, the need for relationship was higher in the face-to-face studies, followed by the online and semi-face-to-face modalities $(4.09 \pm 0.74$ vs. $3.90 \pm 0.82$ vs. $3.99 \pm 0.89 ; \mathrm{F}=5.419 ; p=0.004)$.

In addition, Table 1 defines the BPN according to the access route to university and shows statistically significant differences for all dimensions again. In the need for autonomy, the differences are shown between vocational training and other access routes, with a higher mean value for the first group $(3.62 \pm 0.71$ vs. $3.50 \pm 0.68 ; \mathrm{F}=4.550 ; p=0.011)$. In the need for competence, the differences are shown between university students who accessed through selectivity and those who did so through other routes, showing a higher score in the second group ( $3.96 \pm 0.58$ vs. $4.10 \pm 0.59 ; \mathrm{F}=7.770 ; p<0.001)$. Finally, the students who accessed the university through vocational training showed a higher mean value in the need to relate to others compared to the students who accessed the university through other ways $(4.14 \pm 0.74$ vs. $3.98 \pm 0.89 ; \mathrm{F}=4.396 ; p=0.012)$.

Table 2 shows the relationship between the BPN, age, grade and score of the study participants. In this way, it was shown that the need for autonomy was inversely related to age $(\mathrm{r}=-0.046 ; p<0.05)$ and grade $(\mathrm{r}=-0.078 ; p<0.05)$ and had a positive and direct relationship with the score $(\mathrm{r}=0.042 ; p<0.05)$. The need for competence was positively related to the score $(r=0.213 ; p<0.01)$. Finally, the need to relate to others was positively associated with the score $(\mathrm{r}=0.064 ; p<0.01)$.

Table 2. Relationship between age, grade and basic psychological needs.

\begin{tabular}{cccccc}
\hline & N-C & N-R & Age & Grade & Score \\
\hline N-A & $0.516^{* *}$ & $0.433^{* *}$ & $-0.046^{*}$ & $-0.078^{* *}$ & $0.042^{*}$ \\
N-C & & $0.424^{* *}$ & 0.004 & -0.001 & $0.213^{* *}$ \\
N-R & & & 0.004 & 0.010 & $0.064^{* *}$ \\
Age & & & & $0.190^{* *}$ & $-0.075^{* *}$ \\
Grade & & & & $-0.094^{* *}$ \\
\hline
\end{tabular}

Note 1: N-A: need for autonomy; N-C: need for competence; N-R: need for relationship. Note 2: * Statistically significant differences at the $p<0.05$ level; ${ }^{* *}$ Statistically significant differences at the $p<0.01$ level.

Finally, Table 3 shows the results of a univariate linear model that was used to verify the relationship between the analyzed variables, considering the academic score as the main academic variable. Levene's equality test for the variances determined a value of $p<0.001$, rejecting the null hypothesis and assuming differences between the variables. Likewise, the value of $R^{2}$ was 0.127 . This determines a percentage of explained variance of $12.7 \%$ that must be interpreted with caution, because although there is high variability in the data, a significant trend was demonstrated in the variables analyzed through the significance values and the partial eta with relevant effect sizes. This was because the factors and covariates introduced in the model are associated with cognitive factors associated with personality, which, together with the sample size, generated high variability. Even so, the low $p$-values indicate a real association between the factors, covariates and the dependent variable.

The model determined how the need for autonomy and competence influenced the academic score, giving a moderate effect size in the second case. Likewise, the typology of the university as well as the type of teaching were determined in the same way, giving high effect sizes in both. Finally, it should be noted that the combination of these factors, together with the route of access to the university, were also determining factors for the average score, giving moderate effect sizes. These data support the findings previously reported in the comparison of means. 
Table 3. Univariate linear model for BPN and academic factors.

\begin{tabular}{|c|c|c|c|c|c|c|}
\hline Origin & Sum of Squares & gl & QM & $\mathbf{F}$ & Sig. & $\eta^{2}$ \\
\hline Corrected model & 202.510 & 30 & 6.750 & 13.129 & $* * *$ & 0.127 \\
\hline Intersection & 1733.747 & 1 & 1733.747 & 3372.070 & $* * *$ & 0.555 \\
\hline $\mathrm{N}-\mathrm{A}$ & 13.823 & 1 & 13.823 & 26.886 & $* * *$ & 0.010 \\
\hline $\mathrm{N}-\mathrm{C}$ & 73.408 & 1 & 73.408 & 142.776 & $* * *$ & 0.050 \\
\hline N-R & 0.158 & 1 & 0.158 & 0.307 & 0.579 & 0.000 \\
\hline Area & 2.236 & 1 & 2.236 & 4.348 & * & 0.002 \\
\hline Typology & 8.994 & 1 & 8.994 & 17.492 & $* * *$ & 0.006 \\
\hline Teaching & 10.727 & 2 & 5.364 & 10.432 & $* * *$ & 0.008 \\
\hline Access & 1.782 & 2 & 0.891 & 1.733 & 0.177 & 0.001 \\
\hline Area * Typology & 0.364 & 1 & 0.364 & 0.708 & 0.400 & 0.000 \\
\hline Area * Teaching & 1.387 & 2 & 0.693 & 1.349 & 0.260 & 0.001 \\
\hline Area * Access & 2.990 & 2 & 1.495 & 2.907 & 0.055 & 0.002 \\
\hline Typology * Teaching & 3.480 & 2 & 1.740 & 3.384 & * & 0.002 \\
\hline Typology * Access & 2.510 & 2 & 1.255 & 2.441 & 0.087 & 0.002 \\
\hline Teaching * Access & 8.677 & 4 & 2.169 & 4.219 & ** & 0.006 \\
\hline Area * Typology * Teaching & 2.906 & 1 & 2.906 & 5.652 & * & 0.002 \\
\hline Area ${ }^{*}$ Typology ${ }^{*}$ Access & 0.708 & 2 & 0.354 & 0.688 & 0.503 & 0.001 \\
\hline Area $*$ Teaching $*$ Access & 8.921 & 4 & 2.230 & 4.338 & $* * *$ & 0.006 \\
\hline Typology * Teaching * Access & 4.151 & 1 & 4.151 & 8.074 & ** & 0.003 \\
\hline Error & 1390.774 & 2705 & 0.514 & & & \\
\hline Total corrected & 1593.283 & 2735 & & & & \\
\hline
\end{tabular}

Note 1: N-A: need for autonomy; N-C: need for competence; N-R: need for relationship; QM: quadratic mean. Note 2: * Statistically significant differences at the $p<0.05$ level; ${ }^{* *}$ Statistically significant differences at the $p<0.01$ level; ${ }^{* * *}$ Statistically significant differences at $p<0.005$ level.

\section{Discussion}

The present study aimed to understand the variations in the BPN of students based on academic factors, following a similar line to the studies carried out by Chacón-Cuberos et al. [15], Van Roy et al. [24], Evelein et al. [29], Daumiller et al. [30] or Prieto [31]. In relation to the need for autonomy, it was observed that this was higher in social sciences students, students who accessed university through vocational training and those who attended their degree in person. This need is satisfied when a subject is perceived to have the ability to make their own decisions and carry out academic actions individually and autonomously [19]. Therefore, it seems clear that social science students, who are associated with degrees with a greater predominance of novel, critical and adaptive thinking, develop this need to a greater extent [29].

Moreover, it can be established that the professional training students choose this route of access due to the need for greater practical and competence training, which will help them face university with more knowledge related to their degree, making them more autonomous [32,33]. Finally, it should be noted that this need was positively related to grade, but inversely related to age and grade. This is because those students who achieve higher academic performance will increase their levels of satisfaction, performance and competence [34], while those who advance in grade and age will prioritize other elements to the detriment of autonomy, such as the construction of social relationships [22,35].

The need for competence was higher in students who studied in private centers, those who accessed their university studies through other ways and those who studied online. This need was directly related to the academic score. Justifying these results, Rodríguez 
et al. [36] established that greater feelings of competence tended to develop among students in private schools, especially due to motivational climates that are developed by teachers which are more linked to performance and competition. In this sense, this need-which is satisfied when a student is perceived to have the ability to adequately overcome academic demands-implies higher academic performance [18,37]. It seems evident that it is increased in private universities and online modalities since this type of teaching has been traditionally linked to lower levels of demand because teachers do not monitor the teaching-learning process as intensively [38,39].

It should be highlighted that the need for relationships with others was higher in university students from public institutions, students who accessed their studies through vocational training and those who studied in person. Cerezo et al. [39] and Suarez et al. [40] demonstrate in their studies how face-to-face universities, which predominate in public education, favor to a greater extent the construction of positive social relationships, cooperation among colleagues, the development of recreational activities with other students or the use of methodologies based on cooperative work, which favor the need for relationships with others [41,42].

Finally, it is essential to point out the main limitations of this study. The first is associated with its descriptive and cross-sectional design which does not allow causal relationships to be determined. However, an attempt was made to correct this problem by performing the univariate linear model in order to give more support to the reported findings. As a second limitation, the characteristics of the sample can be highlighted, since randomization methods were not used in its selection. Furthermore, only students from two areas of knowledge were analyzed. Nevertheless, to correct this problem, a large sample with an appropriate sampling error for the population universe was used. The variables used were also one of the main limitations. This is because the other modulating factors of motivation and academic performance were not considered, such as the student's family and work situation, the granting of a scholarship or other psychological factors such as self-concept, stress or resilience.

\section{Conclusions}

Both hypotheses were partially fulfilled. It was determined that the need for autonomy was higher in social sciences students, those who accessed through vocational training and in students who attended their degree in person. In addition, this need was positively related to score, but inversely related to age and grade. The need for competence was higher in students who studied in private centers, those who accessed their university studies through other ways and the students who studied online. Likewise, this need was directly related to the academic score. Finally, it should be noted that the need for relationships was higher in university students from public institutions, students who accessed their studies through vocational training and those who studied in face-to-face universities. The need for relationship correlated positively with the score, although with less strength than other needs. In this way, the relevance of various academic factors in the motivational development of students can be established, from which various educational implications were derived in order to favor academic performance.

Author Contributions: R.C.-C. and M.C.-S. conceived the hypothesis of this study. R.C.-C. and A.J.L.-S. participated in data collection. R.C.-C. and M.C.-S. analyzed the data. R.C.-C. and M.C.-S. contributed to data interpretation of the statistical analysis. R.C.-C. and M.C.-S. wrote the paper. All authors have read and agreed to the published version of the manuscript.

Funding: This research received no external funding.

Institutional Review Board Statement: The study was conducted according to the guidelines of the Declaration of Helsinki.

Informed Consent Statement: Informed consent was obtained from all subjects involved in the study. 
Data Availability Statement: The data presented in this study are available on request from the corresponding author.

Conflicts of Interest: The authors declare no conflict of interest.

\section{References}

1. Murray, J.L.; Arnett, J.J. (Eds.) Emerging Adulthood and Higher Education: A New Student Development Paradigm; Routledge: New York, NY, USA, 2018. [CrossRef]

2. Arnett, J.J.; Mitra, D. Are the features of emerging adulthood developmentally distinctive? A comparison of ages $18-60$ in the United States. Emerg. Adulthood 2020, 8, 412-419. [CrossRef]

3. Ye, Z.; Yang, X.; Zeng, C.; Wang, Y.; Shen, Z.; Li, X.; Lin, D. Resilience, social support, and coping as mediators between COVID-19-related stressful experiences and acute stress disorder among college students in China. Appl. Psychol. Health Well Being 2020, 12, 1074-1094. [CrossRef]

4. Chacón-Cuberos, R.; Badicu, G.; Zurita-Ortega, F.; Castro-Sánchez, M. Mediterranean diet and motivation in sport: A comparative study between university students from Spain and Romania. Nutrients 2019, 11, 30. [CrossRef]

5. DiGuiseppi, G.T.; Meisel, M.K.; Balestrieri, S.G.; Ott, M.Q.; Clark, M.A.; Barnett, N.P. Relationships between social network characteristics, alcohol use, and alcohol-related consequences in a large network of first-year college students: How do peer drinking norms fit in? Psychol. Addict. Behav. 2018, 32, 914. [CrossRef] [PubMed]

6. Li, J.; Han, X.; Wang, W.; Sun, G.; Cheng, Z. How social support influences university students' academic achievement and emotional exhaustion: The mediating role of self-esteem. Learn. Individ. Differ. 2018, 61, 120-126. [CrossRef]

7. Whatnall, M.C.; Patterson, A.J.; Burrows, T.L.; Hutchesson, M.J. Higher diet quality in university students is associated with higher academic achievement: A cross-sectional study. J. Hum. Nutr. Diet. 2019, 32, 321-328. [CrossRef] [PubMed]

8. Richardson, M.; Abraham, C.; Bond, R. Psychological correlates of university students' academic performance: A systematic review and meta-analysis. Psychol. Bull. 2012, 138, 353. [CrossRef]

9. Ramsden, P. Learning to Teach in Higher Education; Routledge: New York, NY, USA, 2003. [CrossRef]

10. Casanova, J.R.; Cervero, A.; Núñez, J.C.; Almeida, L.S.; Bernardo, A. Factors that determine the persistence and dropout of university students. Psicothema 2018, 30, 408-414.

11. Respondek, L.; Seufert, T.; Stupnisky, R.; Nett, U.E. Perceived academic control and academic emotions predict undergraduate university student success: Examining effects on dropout intention and achievement. Front. Psychol. 2017, 8, 243. [CrossRef]

12. van Herpen, S.G.; Meeuwisse, M.; Hofman, W.A.; Severiens, S.E.; Arends, L.R. Early predictors of first-year academic success at university: Pre-university effort, pre-university self-efficacy, and pre-university reasons for attending university. Educ. Res. Eval. 2017, 23, 52-72. [CrossRef]

13. Stupnisky, R.H.; BrckaLorenz, A.; Laird, T.F.N. How does faculty research motivation type relate to success? A test of selfdetermination theory. Int. J. Educ. Res. 2019, 98, 25-35. [CrossRef]

14. Ketonen, E. The role of motivation and academic emotions in university studies: The short-and long-term effects on situational experiences and academic achievement. Hels. Stud. Educ. 2017, 18, 1-130.

15. Chacón-Cuberos, R.; Olmedo-Moreno, E.M.; Lara-Sánchez, A.J.; Zurita-Ortega, F.; Castro-Sánchez, M. Basic psychological needs, emotional regulation and academic stress in university students: A structural model according to branch of knowledge. Stud. High. Educ. 2019, 1-15. [CrossRef]

16. Parhiala, P.; Torppa, M.; Vasalampi, K.; Eklund, K.; Poikkeus, A.M.; Aro, T. Profiles of school motivation and emotional well-being among adolescents: Associations with math and reading performance. Learn. Individ. Differ. 2018, 61, 196-204. [CrossRef]

17. Ibrahim, M.; Baharun, H.; Harun, H.; Othman, N. Antecedents of Intrinsic Motivation, Metacognition and Their Effects on Students' Academic Performance in Fundamental Knowledge for Matriculation Courses. Malays. J. Learn. Instr. 2017, 14, 211-246. [CrossRef]

18. Datu, J.A.D.; King, R.B.; Valdez, J.P.M. Psychological capital bolsters motivation, engagement, and achievement: Cross-sectional and longitudinal studies. J. Posit. Psychol. 2018, 13, 260-270. [CrossRef]

19. Deci, E.L.; Ryan, R.M. Self-determination research: Reflections and future directions. In Handbook of Self-Determination Research; Deci, E.L., Ryan, R.M., Eds.; University of Rochester Press: Rochester, NY, USA, 2002; pp. 431-441.

20. Rigby, C.S.; Ryan, R.M. Self-determination theory in human resource development: New directions and practical considerations. Adv. Dev. Hum. Resour. 2018, 20, 133-147. [CrossRef]

21. Topçu, S.; Leana-Taşcılar, M.Z. The role of motivation and self-esteem in the academic achievement of Turkish gifted students. Gift. Educ. Int. 2018, 34, 3-18. [CrossRef]

22. Fuentes, R.L.; Hernández, P.S. Motivación, necesidades psicológicas básicas y rendimiento académico en Educación Superior. In Aulas Virtuales, Fórmulas y Prácticas; McGraw Hill Education: Madrid, Spain, 2017; pp. 325-331.

23. Campbell, R.; Soenens, B.; Beyers, W.; Vansteenkiste, M. University students' sleep during an exam period: The role of basic psychological needs and stress. Motiv. Emot. 2018, 42, 671-681. [CrossRef]

24. van Roy, R.; Zaman, B. Unravelling the ambivalent motivational power of gamification: A basic psychological needs perspective. Int. J. Hum. Comput. Stud. 2019, 127, 38-50. [CrossRef]

25. Schenkenfelder, M.; Frickey, E.A.; Larson, L.M. College environment and basic psychological needs: Predicting academic major satisfaction. J. Couns. Psychol. 2019, 67, 265-273. [CrossRef] [PubMed] 
26. Bartlett, J.E.; Kotrlik, J.W.; Higgins, C.C. Organizational research: Determining appropriate sample size in survey research appropriate sample size in survey research. Inf. Technol. Learn. Perform. J. 2001, 19, 43-50. [CrossRef]

27. Sheldon, K.M.; Hilpert, J.C. The balanced measure of psychological needs (BMPN) scale: An alternative domain general measure of need satisfaction. Motiv. Emot. 2012, 36, 439-451. [CrossRef]

28. Reggiani, C.F. Necesidades psicológicas básicas, enfoques de aprendizaje y atribución de la motivación al logro en estudiantes universitarios. Estudio exploratorio. Rev. Estilos Aprendiz. 2013, 6, 1-12.

29. Evelein, F.; Korthagen, F.; Brekelmans, M. Fulfilment of the basic psychological needs of student teachers during their first teaching experiences. Teach. Teach. Educ. 2008, 24, 1137-1148. [CrossRef]

30. Daumiller, M.; Stupnisky, R.; Janke, S. Motivation of higher education faculty: Theoretical approaches, empirical evidence, and future directions. Int. J. Educ. Res. 2020, 99, 101502. [CrossRef]

31. Prieto, J.M. Motivación, ansiedad social, práctica de ejercicio físico y rendimiento académico. J. Sport Health Res. 2020, 12 (Suppl. 1), 25-30.

32. Faye, C.; Sharpe, D. Academic motivation in university: The role of basic psychological needs and identity formation. Can. J. Behav. Sci. 2008, 40, 189-199. [CrossRef]

33. McArthur, J. Student involvement in assessment: Involving the whole student in pursuit of social justice and the social good. J. Educ. Res. Assess. Eval. 2020, 26, 1-14. [CrossRef]

34. Carmona-Halty, M.; Schaufeli, W.B.; Llorens, S.; Salanova, M. Satisfaction of Basic Psychological Needs Leads to Better Academic Performance via Increased Psychological Capital: A Three-Wave Longitudinal Study Among High School Students. Front. Psychol. 2019, 10, 2113. [CrossRef]

35. Orkibi, H.; Ronen, T. Basic psychological needs satisfaction mediates the association between self-control skills and subjective well-being. Front. Psychol. 2017, 8, 936. [CrossRef] [PubMed]

36. Rodríguez, M.P.; Cruz, J.; Torregoresa, M. Programa de intervención con entrenadores y padres de familia: Efectos en las conductas del entrenador y el clima motivacional del equipo. Rev. Psicol. Deporte 2017, 26, 181-187.

37. Domenech, F.; Gómez, A. Relación entre las necesidades psicológicas del estudiante, los enfoques de aprendizaje, las estrategias de evitación y el rendimiento. Electron. J. Res. Educ. Psychol. 2011, 9, 463-496.

38. Castro-Sánchez, M.; Zurita-Ortega, F.; Chacón-Cuberos, R. Motivación hacia el deporte en función de variables sociodemográficas en estudiantes universitarios de Granada. J. Sport Health Res. 2019, 11, 55-67.

39. Cerezo, R.; Bernardo, A.; Esteban, M.; Sánchez, M.; Tuero, E. Programas para la promoción de la autorregulación en educación superior: Un estudio de la satisfacción diferencial entre metodología presencial y virtual. Eur. J. Educ. Psychol. 2015, 8, 30-36. [CrossRef]

40. Suarez, J.L.; Anaya, R. Construcción de una identidad participativa: Socialización en el primer año de estudios universitarios. Nóesis Rev. Cienc. Soc. Humanid. 2017, 26, 90-129. [CrossRef]

41. Fraile, J.; Gil-Izquierdo, M.; Zamorano-Sande, D.; Sánchez-Iglesias, I. Self-regulated learning and formative assessment process on group work. Relieve. Rev. Electrónica Investig. Evaluación Educ. 2020, 26, 7. [CrossRef]

42. Ryan, R.M.; Deci, E.L. Self-Determination Theory: Basic Psychological Needs in Motivation, Development, and Wellness; Guilford Publications: New York, NY, USA, 2017. [CrossRef] 